\title{
RELIKTNI VRŠAJI KONTAKTNEGA KRASA
}

\section{Uroš Stepišnik: Reliktni vršaji kontaktnega krasa. Zbirka E-GeograFF 3. Znanstvena založba Filo- zofske fakultete in Oddelek za geografijo, 60 str. Ljubljana, 20II}

Druga letošnja monografija v zbirki E-GeograFF prinaša nova spoznanja o doslej nepoznanih oblikah kontaktnega krasa. Avtor ugotavlja, da se poleg splošno poznanih slepih dolin in ponornih zatrepov na stiku med krasom in nekrasom ali ob vznožju obsežnejših pobočij pogosto pojavlja blago nagnjeno površje, ki ga za razliko od doseda-

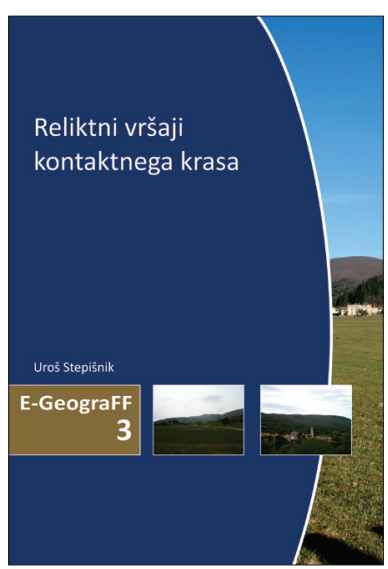
njega prevladujočega mnenja, da so to pedimenti, oziroma pedimentom podobne oblike, tolmači kot rezultat specifičnih procesov na stiku med nekraškim in kraškim geomorfnim sistemom. Trditve argumentira z rezultati terenskega preučevanja teh oblik v skrajnem severozahodnem delu Matarskega (Podgrajskega) podolja med vasema Rodik in Tublje pri Hrpeljah ter na vznožju Vrhpoljskih brd med Lokvijo in Kozino.

Pri tolmačenju teh oblik, ki jim doslej nismo posvečali pozornosti in zanje nimamo niti ustreznega strokovnega termina (v monografiji je predlagan izraz 'reliktni vršaj'), izhaja avtor iz hipoteze, da je nastanek oblik na kontaktnem krasu odvisen predvsem od razmerja med dinamiko fluvialne akumulacije alogenih vodotokov in njihovim korozijskim delovanjem ter od strmca vodotokov v nekraškem povirju. Kadar prevladuje korozija, naj bi nastajale slepe doline in podobne kotanje, ob prevladi akumulacije nad korozijo pa naj bi vodotoki na kraško površje nanašali večje količine nekarbonatnega plavja, z njim prekrili karbonatno podlago in jo zavarovali pred površinsko korozijo. Ko se iz določenega razloga prekine dotok naplavine na vršaj (npr. pretočitev vodotoka ali odstranitev flišnega pokrova v povirju), se razmerje med jakostjo korozije na nepokritem površju in denudacijo na flišni naplavini spremeni v prid korozije, zato imajo te oblike izrazito konveksen podolžni profil. Denudacijski procesi sčasoma v celoti odstranijo flišno naplavino, v karbonatni podlagi pa ostane nekakšen 'odtis' nekdanjega vršaja z značilno pahljačastim tlorisom in konveksnim podolžnim profilom.

Avtor v delu predstavi skoraj celoten niz tovrstnih oblik, od aktivnega vršaja flišnega gradiva na karbonatni podlagi pod vasjo Rodik do vršajem podobnih oblik (reliktnih vršajev) na severni strani Vrhpoljskih brd. Za utemeljevanje hipoteze uporabi tudi zelo nazorne profile električne upornosti tal na teh oblikah, kjer je videti, da so alogene naplavine verjetno res naplavljene prek bolj ali manj zakraselega površja v karbonatni kamnini.

Rezultati skrbnega terenskega dela so v monografiji prikazani korektno, podkrepljeni z vsem potrebnim znanstvenim aparatom, vendar, kot se v znanosti 'spodobi', ne prinašajo končnih rešitev, temveč so nam 'zakomplicirali' dotlej razmeroma preprosto predstavo o procesih na kontaktnem krasu. Delo je nedvomno pomemben prispevek $\mathrm{h}$ 
geomorfološkemu poznavanju tega tipa krasa, saj obravnava nove oblike kontaktnega krasa, ki doslej niso bile podrobneje preučevane. Prav gotovo bo spodbudilo nadaljnje preučevanje tovrstnih oblik, ki imajo ponekod na dinarskem krasu mnogo, še veliko večjih 'sorodnikov' in jim doslej nismo posvečali takorekoč nobene pozornosti.

Celotno delo je strokovni in širši javnosti dostopno na spletni strani Oddelka za geografijo (http://geo.ff.uni-lj.si/sites/default/files/reliktni_vrsaji_kontaktnega_krasa_0.pdf).

Karel Natek 